Issue no. $27 / 2018$

\title{
MOTIVATION ANALYSING AND PREFERENCE SYSTEM OF \\ CHOOSING A WORKPLACE AS SEGMENTATION CRITERIA \\ BASED ON A COUNTRY WIDE RESEARCH RESULT FOCUS ON \\ GENERATION OF Z
}

\author{
Assoc. Prof. Dr. habil. Ágnes Csiszárik-Kocsír \\ Óbuda University, Keleti Faculty of Business and Management, Hungary \\ kocsir.agnes@kgk.uni-obuda.hu \\ Assoc. Prof. Dr. Mónika Garia-Fodor \\ Óbuda University, Keleti Faculty of Business and Management, Hungary \\ fodor.monika@kgk.uni-obuda.hu
}

DOI:10.24193/OJMNE.2018.27.03

\begin{abstract}
In accordance with the current challenges of the Hungarian labour market there is a very strong competition for the proper employees. There is more and more difficult to manage a success recruiting process manly in case of the "new generation". The fact that the generation of $Z$ shall enter the world of work much sooner than the generations ahead of them means that domestic employers will begin to meet more and more gen $Z$ employees. As a result, it is important to understand how the young people of today choose their workplace. What kind of incentives work for them and how, where would they prefer to work, and what kind of a workplace and career they dream about. As the attitude and value system of the Z's differ from the previous generations from several aspects, it is worth taking note of their peculiar characteristic as employees. The study focuses on the generation $Z$ 's preferences in case of workplace selection process. In the frame of quantitative research I examined the segmentation criteria with the help of cluster analysing process. We believe that the findings of the research provide useful information for future employers, to understand the values, motivation tools and expectations of their potential employees and their approach towards the world of work.
\end{abstract}

Keywords: Z generation, workplace selection, quantitative research, segmentation. 
Issue no. $27 / 2018$

\section{Literature review}

When thinking the domestic labour market challenges, we can state that the lack of quantity and / or quality of labour is a problem on the rise. For employers, it's becoming more and more important to find and keep good labour. Labour shortage doesn't impact certain sectors, but the entirety of the economy. Nowadays, not only lacking fields (technicians, IT experts, medical doctors) are troubled by labour shortage, even in so-called "blue-collar" sectors, we can see a lack of employees (f. e. welders, forklift drivers, etc.). Many times, one must use headhunting methods to find physical labour as well (Hrportal, 2017).

Apart from recruitment and labour-keeping problems, further factors make things harder in the form of making different generations work with each other, troubling HR experts. As a difference in age impacts cooperation, joint work may prove difficult for both younger and older generations (Ian et.al, 2017).

It's pretty hard to create a work atmosphere in which employees with different value systems, and socialisation backgrounds can feel themselves good, thinking it optimal, attractive and motivational. It's no coincidence that in recent years, more and more research focused on how the ranking of tools motivating employees changed. Seeing as the change has been increasingly intense for the HR profession.

Generation researchers define generations based on youth-age cohort experiences: which are the common experiences which may affect the later personalities and value systems of the age group in question (Töröcsik, 2003).

Research states that the economic-social environment, in which the given generation went through socialisation is important. The impulses and impressions they were subjected to, or perhaps the objects in their environment, and happenings during their lives all have a high impact on their performance on the labour market, and their attitude towards work (Tari, 2011).

This study focuses on the $\mathrm{Z}$ generation, therefore, we would like to introduce the attributes of this age group for now. The members of the $\mathrm{Z}$ generation are completely born in the World determined and dominated by the advancement of digital technology. They live in a much faster rhythm than their predecessors, and if they don't like something - f. e. a job they're literally born ready to change immediately. They are a different World from their 
precursors: as modern technological solutions, IT, and the online World matured together with them, they became parts of their personalities.

Members of the $\mathrm{Z}$ generation are brave, never lack initiative, less doubtful of their own skills and possibilities (Lazányi, 2015). They are described by a practical perspective, they value the freedom of the individual, and the immediate environment being devoid of formalities. They build a new World, as they aren't believers in traditional office work culture, but using the tools of mobile phones and the internet, they can complete their tasks anywhere in the World, and create their virtual communities. Spiritualist literature calls them crystal generation, part of the star generations. The attribute of the generation is that they're more smart than wise, as they're well-versed in the World of technology. They aren't defined by words and feelings, and they can realise their ideas even with high costs. It's common for them, and reflects their value system, that of two jobs, they'll probably choose the one where there's a valid CSR strategy, and the thought pattern of the employer is environment-friendly (Ridderstrale, 2004).

However, it's also a fact that switching between jobs is completely natural for them. They move without any compromise, they jump from workplace to workplace like how monkeys from branch to branch, in case they feel that they need to. They're never stuck with a company, and they never worry that they don't have an assured wage, and fixed desk somewhere. For members of the digital generation, personal relations are definitive, and they use internet as a tool for keeping currently existing friendships and connections with others. The five most popular jobs are vets, teachers, policemen, medical doctors, and of course, football players. Though it's true that $64 \%$ would rather be responsible for themselves when they become an adult, instead of being employed by someone. This is important information for companies. We have to support an organisational form, and create an organisational culture, which aids self-sustaining work, and lacks high hierarchy. The trend of organisations becoming more 'flat' will continue into the XXI. Century (Kissné, 2010; Tari, 2010).

\section{Material and methods}

In this study, we will introduce partial results of a research project. In the framework of a multi-phase project, we analysed the career- and job choice influencing factors for the $\mathrm{Z}$ 
Issue no. $27 / 2018$

generation using qualitative and quantitative methods as well. Our goal was to give points of interest for the employees focusing on the $\mathrm{Z}$ generation (as well), which can be used as milestones of an employer branding oriented towards a target group.

In the first phase of the research project, we conducted qualitative analyses: thirty mini-focus group interviews with members of the $\mathrm{Z}$ generation, and seven interviews with HR and Employer Branding experts, semi-structured in both cases (Fodor - Jäckel, 2017). During the mini-focus group, recruiting members was done using the snowball method, with a single filter: the participant has to be a member of the $\mathrm{Z}$ generation, based on their age. The maximum number of participants in a focus group was 6 , and in all cases, we analysed groups heterogeneous for gender, in order to better compare opinions. The interviews were recorded. The results were processed using traditional content analysis method.

In case of the expert interviews conducted with the representatives of the employer side, we asked HR leaders, and recruitment HR specialists of manufacturer, producer, and development large- or multi-national enterprises for their experiences and opinions (Duma, 2014). The goal of the qualitative phase was identification, structuring hypotheses, and preparation for the second phase, the quantitative phase. During the quantitative analysis after this, we used a sampling method of non-representative snowball selection, and tried to find participants while keeping the age filter as it was in the previous phase. During the analysis, we used a questionnaire formulated based on the results of the qualitative research, and with the help of the CAPI method, we received 1178 replies adhering to the requirements.

In this research phase, we were looking for answers for the following questions:

- What kind of preference system describes participants during the choice of job?

- How effective our analysed motivational factors for this generation's increase in efficiency of labour?

- What are the generation's preference in information channels, when seeking information on their workplace or career?

- In what way, and with what conditions would they wish to employ the 'mentor aiding career' described as the result of the qualitative research? Due to what service attributes would they consider it really useful? 
Issue no. $27 / 2018$

\section{Results}

In this study, we will introduce a partial result of the quantitative phase, in which the focus was on the analysis of the workplace choice preference as a segmentation attribute.

Before the detailed description of these multi-variable results, we think it's important to briefly view our previous research results. At first we would like to exam how can we effectively motivate the $\mathrm{Z}$ workers, secondly we analysed the ranking of drivers influencing the selection of workplace in case of $\mathrm{Z}$ generation.

\subsection{Motivation in case of $\mathbf{Z}$ workers}

The word motivation - or incentive, inspiration - originates from the Latin word "movere", which means to move, movement (Klein - Klein, 2008). Motivation provides an explanation for the observable behaviour of people. The understanding of the various motivational theories and tools is necessary for the selection of the best incentives and drivers ensuring the most efficient solution in case of employees as well. From the aspect of Employer Branding and management theory, it is important to know that performance is nothing but the product of abilities multiplied by motivation (Tóthné, 2004). The result of a well-designed incentive plan is the performance expected by the organization and the satisfaction of employees. Leaders are able to have an influence on this, and with the proper range of motivational tools they are able to generate an efficient stimulation in order to achieve the desired results (Göndör, 2003).

Motivation theories were first studied to a deeper extent after the XVII. century, and the most popular theories regarding consumer behaviour and consumption psychology were drafted in the XX. century (Kópházi, 2007; Tóth, 2009).

After the elaboration of content theories - Maslow, Herzberg - process theories were developed, Vroom for example revealed that it is important that workers should feel that they are able to solve the assigned task, and receive a reward for the performed work, which will appeal to them, and provide a motivation throughout the performance of tasks. Furthermore, he also emphasized that during a work process the factors driving a particular person must be taken into account, and the incentive system must be elaborated accordingly. It is important that performance should have to be measurable, since that is the only way of providing accurate reward (Garda, 2009). 
Issue no. $27 / 2018$

The efficiency of external rewarding is questioned now by the motivation 3.0 theory. Pink proved that not only biologic and external rewarding can serve as motivation. He highlighted the fact that motivation can also be counterproductive in terms of efficiency: he compared reward to caffeine - it keeps people at a fast pace only for a few hours, but after the effect is gone, things will get worse (Pink, 2010).

Pink emphasized the importance of internal motives and their motivational impact on the efficiency and productivity of work. Though it is not well known in Hungary, a number of companies in the USA apply the results-only working environment (RAWE) concept successfully (Howell, 2000). The range of HR tools which can be applied effectively in case of the various generations is important from the aspect of employer branding. There are several studies examine the motivation and attitude of youngsters (Lazányi, 2014a, 2014b), generation differences are not the focus points of these. Our results reveal that the most important driver for generation $\mathrm{Z}$ is still a high salary, although promotion opportunities and the promise of a good team, good atmosphere also came close to the top.

The results of the quantitative research are in accordance with the conclusions of the qualitative research, where during the discussions about how they select their workplace, the first factor respondents mentioned was the payment as well, and the most frequently mentioned drivers also included a good working atmosphere, attractive environment, and a good team, where they feel good while performing their job.

The results of the qualitative analysis show that fringe benefits and more free time also serve as great motivational factors, being on top of the preference list. While these were also important in the quantitative research, they were not perceived as the most important ones.

A creative working environment and the opportunity to implement their own ideas seemed to be more important than a good cafeteria system.

\begin{tabular}{|l|r|}
\hline To what extent do the following factors motivate you for a better performance at work? & average \\
\hline higher salary & 3,64 \\
\hline opportunity for promotion at the workplace & $\mathbf{3 , 4 6}$ \\
\hline opportunity for a career abroad & 2,60 \\
\hline
\end{tabular}


Issue no. $27 / 2018$

\begin{tabular}{|l|r|}
\hline greater independence in decisions & 3,08 \\
\hline more free time, less work & 3,21 \\
\hline opportunity to implement own ideas & 3,25 \\
\hline to work in a good team & $\mathbf{3 , 4 7}$ \\
\hline opportunities to take part in training sessions, professional development courses & 2,97 \\
\hline other fringe benefits (cafeteria) & 3,22 \\
\hline modern, creative working environment & 3,32 \\
\hline
\end{tabular}

Table 1.Ranking of proper motivation tools

Source: own research $2017 N=1177$

The opinion of experts also confirm the conclusions of our research, that even though the salary is important for the younger generations, it is not enough to retain members of this generation at a certain workplace. The employer brand is becoming more and more important for them, and consequently, their desire to be proud of working for that particular company. A pleasant atmosphere, and development and career opportunities are also important, as well as the fact that they should enjoy their job. If they are satisfied with these factors, there is a chance that they might spend longer time at a workplace. (Kissné, 2014)

\subsection{The ranking of drivers influencing the selection of workplace}

An employer must be familiar with the factors which play an important role in the selection of workplaces, when potential employees are making up their minds which job or work opportunity they should choose. It is not by chance that a number of practicing HR experts believe that today an HR expert has to be a good salesman as well: they have to sell the announced position, to make the workplace appealing both for the people who work there and for those who they are seeking to hire. In order for an employer to be able to create such conditions at the workplace and to determine such an incentive package which is attractive for the candidates they are actually attempting to recruit, they must understand their expectations, values and the range of factors these people consider when selecting their workplace. According to HR experts, the high level of motivation of employees might take a company to the top, if those people feel appreciated and see that their personal opinions, ideas, performance and development actually contribute to the advancement of the company. If they can address the top leaders with their problems, because employees and the 
management speak the same language. If the company feels like their own, and they are proud to have a desk there $(\mathrm{X})$, to work as one team $(\mathrm{Y})$, and the company collects waste selectively and takes care of the environment $(Z)$. The reason doesn't matter, they just want to be proud of the company (Kissné, 2014).

The research conducted in 1999 already revealed that employers have to face something new, an altered set of preferences when it comes to motivation at the workplace. According to the survey, employees can be best driven by (1) interesting work, (2) the recognition of the implemented work, and (3) the sense of being an insider. Only after that came (4) a secure workplace, and (5) a good salary. The opportunity for development was the $6^{\text {th }}$ on the list, and it was followed on the $7^{\text {th }}$ place by good working conditions. These results were surprising, since leaders expected the factors of good salary, a secure workplace, the opportunity for promotion/development and interesting work to be on the top of the list (Kovach, 1999).

According to the Best Workplace 2012 research, respondents were seeking a (1) secure livelihood, (2) constant development and (3) diverse, interesting tasks at the ideal workplace, but almost every fourth respondent listed (4) professional challenges and (5) the opportunity for flexible work to be one of the top three most important factors. About 70 percent of them desires to work at a place where (6) they are appreciated financially and morally as well, and also more than 30 percent listed amongst the priorities that (7) the company should be steady and reliable, where they can (8) work in a good team, in a pleasant atmosphere.

Besides the factors which are important for everyone - such as a secure livelihood other attributes including social reputation, usefulness, helping others, cooperation with clients, controlling others and development also became important for employees, nevertheless, social responsibility, the protection of the environment and the mood present at the company is gaining more and more attention as well (Kissné, 2010; Boyett-Boyett, 2010).

According to the results of our quantitative research, when considering which job, workplace to choose, one of the major decisive factors is the opportunity for a promotion and professional development. It is esteemed even higher than a high salary for generation $\mathrm{Z}$. The ranking of factors which play a role in the selection of a workplace looks quite similar to the 
Issue no. $27 / 2018$

range of efficient motivational tools. It seems obvious that for this generation, offering a high salary and a good cafeteria, fringe benefits is not enough, as they are seeking for a company where they can realize their dreams, where they can fulfil a great and successful career path, and where they can work in a good team and atmosphere.

The understanding of these aspects is important, because it clearly demonstrates the conditions a workplace should offer, the fields it should improve in order to appeal to the young generation, and to be able to retain its workforce. Today it poses an ever increasing challenge for employers. Unlike earlier, when foreign ownership, the "multinational" characteristic of a company was attractive, today these do not matter at all for young people when selecting their workplace. It is also important to see that compared to predictable and fix working hours, the desire to fulfil a diverse scope of duties and to receive creative tasks seems even more significant. A modern working environment meaning that they should not have to travel for too long to their workplace, and flexible working hours are - similarly to the results of our qualitative research - significant aspects for this generation, even greater than the awareness and reputation of the company. It is good news for small and medium sized enterprises, who are able to offer more attractive opportunities in these fields, compared to the multinational corporations applying standard elements who are less flexible from a number of aspects.

\begin{tabular}{|l|r|}
\hline Factors influencing the selection of workplace & average \\
\hline the financial background of the company and the stability of its position on the \\
market & 3,40 \\
\hline the reputation and general perception of the company & 3,07 \\
\hline opportunities for promotion at the company & $\mathbf{3 , 4 9}$ \\
\hline the life-work balance should remain intact & 3,40 \\
\hline opportunity for working abroad & 2,44 \\
\hline to have other allowances, benefits besides the salary & 3,13 \\
\hline the company should have foreign ownership & 1,83 \\
\hline predictable, fix working hours & 2,99 \\
\hline opportunity for professional development & $\mathbf{3 , 4 8}$ \\
\hline diverse scope of duties & 3,24 \\
\hline
\end{tabular}


Issue no. $27 / 2018$

\begin{tabular}{|l|r|}
\hline creative tasks & 3,17 \\
\hline career opportunity & 3,44 \\
\hline company should employ many people & 2,13 \\
\hline high salary & $\mathbf{3 , 4 7}$ \\
\hline opportunity for continuing training and education & 3,12 \\
\hline good team spirit & $\mathbf{3 , 4 7}$ \\
\hline company should implement corporate social responsibility & 2,90 \\
\hline company with a national reputation & 2,31 \\
\hline low average age of employees & 2,43 \\
\hline Hungarian ownership & 1,99 \\
\hline multinational company & 2,06 \\
\hline I should be employed by the company, and not through a work agency & 3,25 \\
\hline flexible working hours & 3,02 \\
\hline modern working environment & 3,24 \\
\hline the distance of the workplace from my home & 3,23 \\
\hline
\end{tabular}

Table2.Ranking of factors influencing the selection of workplace

Source: own research $2017 N=1177$

In our research project, we focused on the $\mathrm{Z}$ generation, seeking the things that make a workplace enticing for $\mathrm{Z}$ generation members, and what motivates them to be efficient in their work.

According to our research results, wages are no longer enough for $\mathrm{Z}$ gen members, as they considered top priorities within the preference system to include opportunities for promotion, the chance to belong to a good team, and a comfortable workplace atmosphere.

\subsection{Factor analysis of variables determining choice of workplace}

The preference system of choosing a workplace can be a good segmentation factor for Employer Branding strategy. Based on this, we can easily characterise the segments based on who considers what important, what's the most notable factor when choosing a workplace. This may help employers in knowing which segments will consider their offers the most enticing, and what HR-communication and Employer Branding solutions they can target on which target groups. In order to understand what factors belong into the same category 
Issue no. $27 / 2018$

according to the participants' opinions, we conducted a factor analysis for preferences in choosing a workplace.

\begin{tabular}{|c|c|c|c|c|c|}
\hline $\begin{array}{c}\text { Elements } \\
\text { I want (a/an): }\end{array}$ & $\begin{array}{c}\text { Reputation } \\
\text { and } \\
\text { Stability } \\
\text { factor }\end{array}$ & $\begin{array}{c}\text { Career and } \\
\text { development } \\
\text { opportunities }\end{array}$ & $\begin{array}{l}\text { Trendy } \\
\text { elements }\end{array}$ & $\begin{array}{l}\text { Leisure } \\
\text { and } \\
\text { security }\end{array}$ & $\begin{array}{c}\text { Extra } \\
\text { demands }\end{array}$ \\
\hline Multi-national company & 0,769 & 0,060 & $-0,042$ & 0,048 & 0,101 \\
\hline Foreign-owned company & 0,739 & 0,055 & $-0,057$ & $-0,125$ & 0,185 \\
\hline Nationally known company & 0,731 & $-0,019$ & 0,082 & 0,192 & 0,011 \\
\hline Company with many employees & 0,713 & 0,068 & 0,038 & 0,109 & 0,038 \\
\hline $\begin{array}{l}\text { Company with younger employees on } \\
\text { average }\end{array}$ & 0,618 & 0,033 & 0,175 & $-0,046$ & 0,188 \\
\hline Hungarian-owned company & 0,579 & $-0,179$ & 0,142 & 0,287 & $-0,204$ \\
\hline Company with opportunities abroad & 0,516 & 0,329 & 0,053 & $-0,268$ & 0,233 \\
\hline Company with opportunities for promotion & $-0,034$ & 0,803 & 0,112 & 0,144 & 0,112 \\
\hline $\begin{array}{l}\text { Company with opportunities for } \\
\text { advancement }\end{array}$ & 0,015 & 0,798 & 0,137 & 0,077 & 0,176 \\
\hline $\begin{array}{l}\text { Company with opportunities for } \\
\text { professional development }\end{array}$ & $-0,016$ & 0,667 & 0,300 & 0,088 & $-0,030$ \\
\hline $\begin{array}{l}\text { Company with opportunities for } \\
\text { postgraduate training }\end{array}$ & 0,224 & 0,501 & 0,366 & 0,024 & 0,094 \\
\hline Varied tasks & 0,017 & 0,209 & 0,759 & $-0,017$ & 0,122 \\
\hline Creative tasks & 0,093 & 0,178 & 0,728 & $-0,055$ & 0,149 \\
\hline Good team effort & 0,000 & 0,148 & 0,553 & 0,347 & 0,103 \\
\hline Company with proper CSR & 0,231 & 0,075 & 0,461 & 0,214 & $-0,188$ \\
\hline Simple, fixed work time & 0,124 & 0,038 & $-0,149$ & 0,618 & $-0,003$ \\
\hline $\begin{array}{l}\text { Balance between work and family to } \\
\text { remain }\end{array}$ & $-0,196$ & 0,007 & 0,264 & 0,577 & 0,093 \\
\hline The job to be close to my home & $-0,036$ & $-0,059$ & 0,058 & 0,533 & 0,348 \\
\hline $\begin{array}{l}\text { Company with a stable financial } \\
\text { background }\end{array}$ & 0,043 & 0,410 & 0,013 & 0,479 & 0,034 \\
\hline
\end{tabular}


Issue no. $27 / 2018$

\begin{tabular}{|l|r|r|r|r|r|}
\hline $\begin{array}{l}\text { Employee contract, without being a } \\
\text { member through another organisation }\end{array}$ & 0,097 & 0,186 & 0,127 & 0,358 & 0,006 \\
\hline $\begin{array}{l}\text { Company with good reputation and } \\
\text { consumer attitude }\end{array}$ & 0,318 & 0,301 & 0,032 & 0,348 & 0,092 \\
\hline Flexible work time & 0,192 & 0,014 & 0,306 & $-0,073$ & 0,636 \\
\hline High wages & 0,073 & 0,208 & $-0,145$ & 0,332 & 0,615 \\
\hline Modern work environment & 0,176 & 0,163 & 0,313 & 0,073 & 0,591 \\
\hline
\end{tabular}

Table 3: Factors of variables determining choice of workplace

Source: personal research, $2017 \mathrm{~N}=1177$ (KMO=0,852 total variance $=50,342 \%)$

According to the four-, five- and six-factor tests - where the KMO value was 0,852 for each, and total variance remained above $50 \%$ - there were elements, which always moved together, regardless of factor number. This proves these factors are firmly connected in the value interpretation of employees. Such were the attributes of V1-V3 factors, which functioned as strongly connected structures in all analyses.

There were also wandering elements - meaning elements integrating into different groups based on number of factors - like "company's financial background" and "general attitude towards is", and the one where participants said "I want to be a contracted employee in the company". These are either "stability factors", or made up a separate group for higher factor numbers. Based on statistical indicators, and the experts' opinions, we considered the five-factor trial to be sufficiently valid.

\subsection{Clusters based on preference for workplace choice}

After the factor analysis, we wanted to conduct a segmentation on the sample using the K-means method of cluster analysis and the factor groups (Table 4). Based on the results, we can differentiate between five groups of preferences for choice in workplace. As far as group sizes go, the two segments became "Those wanting stability" (314), and "Ambitious ones" (307). The former is made up of employees who prefer companies which have many employees, and are known throughout the country, multi-national, or well-known Hungarian companies with good reputation. The latter, "Ambitious ones" think that career and development opportunities are the most important, and they also consider "trendy" factors of choice in workplace important, such as "flexible work time", or "modern environment". 
"Trendy employees" are the ones seeking good team effort, a varied and creative work environment, and think that it's important to be an employee of a company which is known for its CSR, in other words, is sensitive to social and environmental problems. "Those hunting extra offers" are employees who seek their job based on "Extra demands". They wish to work in a modern, comfortable company with a good environment in a flexible work time, for high wages.

\begin{tabular}{|c|c|c|c|c|c|}
\hline & \multicolumn{5}{|c|}{ Clusters } \\
\hline \multirow{2}{*}{ Factors } & $\begin{array}{c}\text { Those wanting } \\
\text { stability } \\
\mathrm{N}=307\end{array}$ & $\begin{array}{c}\text { Trendy } \\
\text { employees } \\
\mathrm{N}=250\end{array}$ & $\begin{array}{c}\text { Those hunting } \\
\text { extra offers } \\
\mathrm{N}=165\end{array}$ & $\begin{array}{c}\text { Those wanting } \\
\text { reputation and } \\
\text { stability } \\
\mathrm{N}=140\end{array}$ & $\begin{array}{c}\text { Ambitious } \\
\text { ones } \\
\mathrm{N}=314\end{array}$ \\
\hline $\begin{array}{c}\text { Reputation and } \\
\text { Stability factor }\end{array}$ & 0,8924 & $-0,5635$ & $-0,5155$ & 0,8955 & $-0,5522$ \\
\hline $\begin{array}{c}\text { Career and } \\
\text { development }\end{array}$ & 0,3540 & 0,0224 & $-1,3331$ & $-0,6662$ & 0,6336 \\
\hline Trendy elements & 0,0577 & 0,4344 & $-0,6721$ & $-0,3919$ & 0,1256 \\
\hline Leisure and security & 0,6547 & 0,1976 & 0,3569 & $-1,2769$ & $-0,4157$ \\
\hline Extra demands & 0,2194 & $-1,0489$ & 0,6365 & $-0,6109$ & 0,5585 \\
\hline
\end{tabular}

Table 4: Clusters based on preference for workplace choice

Source: personal research, $2017 N=1177$

\section{Socio-demographic attributes of clusters by preference of workplace choice}

We also described the various factors by gender and age, and using a crosstab analysis, Pearson's Chi-square test's significance value, and supplementing all this with the corr. standardized residuum, we analyzed relations and their levels. Among "Trendy employees", we can see that compared to the estimated value, men are less, and women are more in numbers. Compared to the ratios within the sample, ladies are more concentrated, whereas in the "Those wanting reputation and stability" group, ratios are switched, and there are less females, and more males. As for the other clusters - similarly to the sample average males and females had a near-balance between them. 
Issue no. $27 / 2018$

\begin{tabular}{|c|c|c|c|c|c|c|}
\hline Gender ratio (\%) & $\begin{array}{c}\text { Those } \\
\text { wanting } \\
\text { stability }\end{array}$ & $\begin{array}{c}\text { Trendy } \\
\text { employees }\end{array}$ & $\begin{array}{c}\text { Those } \\
\text { hunting } \\
\text { extra offers }\end{array}$ & $\begin{array}{c}\text { Those } \\
\text { wanting } \\
\text { reputation } \\
\text { and stability }\end{array}$ & $\begin{array}{c}\text { Ambitious } \\
\text { ones }\end{array}$ & $\begin{array}{l}\text { Sample } \\
\text { average }\end{array}$ \\
\hline male & 50,49 & 42,80 & 50,91 & 65,00 & 51,91 & 51,00 \\
\hline Corr. std. residuum & $-0,217$ & $-2,930$ & $-0,031$ & 3,525 & 0,369 & \\
\hline female & 49,51 & 57,20 & 49,09 & 35,00 & 48,09 & 49,00 \\
\hline Corr. std. residuum & 0,217 & 2,930 & 0,031 & $-3,525$ & $-0,369$ & \\
\hline Total & 100 & 97,1 & 100,0 & 103,5 & 100,4 & 100,0 \\
\hline
\end{tabular}

Table 5: Attributes of preference for workplace choice clusters, by gender ratio

Source: personal research, $2017 N=1177 ;$ sig=0,001

If we take a look at the gender ratios, we can see that for Trendy employees, those below 18 are less than the estimation, and those between 32 and 37 are more. The overrepresentation of this age group, similarly to the below 18 age group, can also be observed for those hunting extra offers. This shows us that we can find more people who want higher wages, flexible work times, modern environments by default in the group of those at the beginning of their careers. In the case of this age group, the reason should be the lack of experiences, and the specific value system of the generation. Whereas for "older", 32-37 years old participants, this preference should rather constitute the perspectives of changing workplaces, in other words, a form of motivational factor. Due to their work experience, they demand that their new workplace offers a better work time / free time balance, with a higher wage. Knowing the preference system for choosing a workplace related to clusters, it's no surprise that both "Reputation and stability" and "Ambitious" groups showed less amount of participants from the $30+$ age group. 
Issue no. $27 / 2018$

\begin{tabular}{|c|c|c|c|c|c|c|}
\hline Age groups & $\begin{array}{l}\text { Those } \\
\text { wanting } \\
\text { stability }\end{array}$ & $\begin{array}{c}\text { Trendy } \\
\text { employees }\end{array}$ & $\begin{array}{l}\text { Those } \\
\text { hunting } \\
\text { extra offers }\end{array}$ & $\begin{array}{c}\text { Those } \\
\text { wanting } \\
\text { reputation } \\
\text { and } \\
\text { stability }\end{array}$ & $\begin{array}{c}\text { Ambitious } \\
\text { ones }\end{array}$ & $\begin{array}{l}\text { Sample } \\
\text { average }\end{array}$ \\
\hline Below $18(\%)$ & 6,19 & 1,20 & 9,70 & 7,86 & 4,78 & 5,44 \\
\hline Corr. std. residuum & 0,671 & $-3,332$ & 2,598 & 1,342 & $-0,607$ & \\
\hline $18-21(\%)$ & 31,27 & 23,20 & 19,39 & 32,14 & 30,57 & 27,81 \\
\hline Corr. std. residuum & 1,576 & $-1,832$ & $-2,601$ & 1,220 & 1,278 & \\
\hline $21-25(\%)$ & 33,88 & 40,00 & 24,85 & 33,57 & 39,49 & 35,37 \\
\hline Corr. std. residuum & $-0,639$ & 1,724 & $-3,050$ & $-0,475$ & 1,782 & \\
\hline $26-31(\%)$ & 14,33 & 11,60 & 12,12 & 18,57 & 16,88 & 14,63 \\
\hline Corr. std. residuum & $-0,169$ & $-1,526$ & $-0,982$ & 1,408 & 1,320 & \\
\hline $32-37(\%)$ & 14,33 & 24,00 & 33,94 & 7,86 & 8,28 & 16,75 \\
\hline Corr. std. residuum & $-1,321$ & 3,458 & 6,376 & $-3,003$ & $-4,695$ & \\
\hline Total (\%) & 100,00 & 100,00 & 100,00 & 100,00 & 100,00 & 100,00 \\
\hline
\end{tabular}

Table 6: Attributes of preference for workplace choice clusters, by age

Source: personal research, $2017 \mathrm{~N}=1177 ;$ sig=0,000

Effect of parents' educational level on the workplace preference of children. In the cases of various clusters, we also analyzed the highest level of education of the participants' parents. This perspective showed the following connections. Among those wanting extras, there are more mothers with primary education only then assumed prior to conducting the analysis, and there are less with secondary education. As for the Ambitious group, the less relevant group is those with basic education.

\begin{tabular}{|c|c|c|c|c|c|c|}
\hline $\begin{array}{c}\text { Mother's highest } \\
\text { education / cluster }\end{array}$ & $\begin{array}{c}\text { Those } \\
\text { wanting } \\
\text { stability }\end{array}$ & $\begin{array}{c}\text { Trendy } \\
\text { employees }\end{array}$ & $\begin{array}{c}\text { Those } \\
\text { hunting } \\
\text { extra offers } \\
\text { wanting } \\
\text { reputation } \\
\text { and } \\
\text { stability }\end{array}$ & $\begin{array}{c}\text { Ambitious } \\
\text { ones }\end{array}$ & $\begin{array}{c}\text { Sample } \\
\text { average }\end{array}$ \\
\hline Primary $\boldsymbol{e d}$ (\%) & $\mathbf{6 , 8 4}$ & $\mathbf{1 0 , 0 0}$ & $\mathbf{1 8 , 1 8}$ & $\mathbf{1 0 , 0 0}$ & $\mathbf{5 , 1 0}$ & $\mathbf{9 , 0 1}$ \\
\hline
\end{tabular}


Issue no. $27 / 2018$

\begin{tabular}{|c|c|c|c|c|c|c|}
\hline Corr. std. residuum & $-1,547$ & 0,614 & 4,435 & 0,434 & $-2,832$ & \\
\hline Secondary ed. (\%) & $\mathbf{4 9 , 8 3 7}$ & $\mathbf{5 4 , 0 0 0}$ & $\mathbf{5 0 , 9 0 9}$ & $\mathbf{5 3 , 5 7 1}$ & $\mathbf{5 3 , 1 8 5}$ & $\mathbf{5 2 , 2 1 1}$ \\
\hline Corr. std. residuum & $-0,969$ & 0,638 & $-0,361$ & 0,343 & 0,404 & \\
\hline Higher education (\%) & $\mathbf{4 3 , 3 2 2}$ & $\mathbf{3 6 , 0 0 0}$ & $\mathbf{3 0 , 9 0 9}$ & $\mathbf{3 6 , 4 2 9}$ & $\mathbf{4 1 , 7 2 0}$ & $\mathbf{3 8 , 7 7 6}$ \\
\hline Corr. std. residuum & 1,902 & $-1,015$ & $-2,237$ & $-0,607$ & 1,251 & \\
\hline
\end{tabular}

Table 7: Connection between mother's educational level, and participant's workplace preference Source: personal research, $2017 \mathrm{~N}=1177$; sig=0,000

\begin{tabular}{|c|c|c|c|c|c|c|}
\hline $\begin{array}{c}\text { Father's highest education / } \\
\text { cluster }\end{array}$ & $\begin{array}{c}\text { Those } \\
\text { wanting } \\
\text { stability }\end{array}$ & $\begin{array}{c}\text { Trendy } \\
\text { employees }\end{array}$ & $\begin{array}{c}\text { Those } \\
\text { hunting } \\
\text { extra offers }\end{array}$ & $\begin{array}{c}\text { Those } \\
\text { wanting } \\
\text { reputation } \\
\text { and } \\
\text { stability }\end{array}$ & $\begin{array}{c}\text { Ambitious } \\
\text { ones }\end{array}$ & $\begin{array}{c}\text { Sample } \\
\text { average }\end{array}$ \\
\hline Primary ed. (\%) & $\mathbf{1 1 , 7 2 6}$ & $\mathbf{1 4 , 8 0 0}$ & $\mathbf{1 5 , 7 5 8}$ & $\mathbf{8 , 5 7 1}$ & $\mathbf{7 , 3 2 5}$ & $\mathbf{1 1 , 3 9 5}$ \\
\hline Corr. std. residuum & 0,213 & 1,910 & 1,902 & $-1,120$ & $-2,651$ & \\
\hline Secondary ed. (\%) & $\mathbf{4 7 , 5 5 7}$ & $\mathbf{5 2 , 0 0 0}$ & $\mathbf{5 0 , 3 0 3}$ & $\mathbf{5 3 , 5 7 1}$ & $\mathbf{5 7 , 6 4 3}$ & $\mathbf{5 2 , 2 9 6}$ \\
\hline Corr. std. residuum & $-1,934$ & $-0,106$ & $-0,553$ & 0,322 & 2,216 & \\
\hline Higher education (\%) & $\mathbf{4 0 , 7 1 7}$ & $\mathbf{3 3 , 2 0 0}$ & $\mathbf{3 3 , 9 3 9}$ & $\mathbf{3 7 , 8 5 7}$ & $\mathbf{3 5 , 0 3 2}$ & $\mathbf{3 6 , 3 1 0}$ \\
\hline Corr. std. residuum & 1,868 & $-1,152$ & $-0,683$ & 0,406 & $-0,550$ & \\
\hline
\end{tabular}

Table 8: Connection between father's educational level, and participant's workplace preference Source: personal research, $2017 \mathrm{~N}=1177$; sig $=0,03$

On the one hand, the results are interesting from the perspective of there being a connection between the educational level of parents, and the workplace preference of their children. On the other hand, if we take a look at the level of relations, we can see children wanting high wages, and flexible work times, whose parents probably don't have such privileges due to their low educational level.

\section{Summary}

In light of current labour market challenges, we can state that one of the most notable keys to corporate success is human resource. Successful recruitment and successfully keeping labour force are key factors in keeping competitiveness. We must know our current and 
Issue no. $27 / 2018$

future employees for proper HR-communication, and Employer Branding. The goal of this study is to analyse the factors influencing the choice of workplace focusing on the $\mathrm{Z}$ generation, and to unearth how this influence works. Based on the results of the research, we differentiate between segments, target groups based on their workplace preferences. The groups were also characterised based on their socio-demographic attributes, therefore, potential employers can obtain an idea on which segment is described by what attributes, based on their demands for workplace, and demographic background. The results, I believe, offer help for an Employer Branding strategy needed for recruitment and keeping labour force as well, by getting to know potential employees in-depth.

In the next part of the research, we aim to further segment the sample, and by characterising by HR-motivational tools, we wish to find more target group attributes, which - we believe - will offer further useful information for HR and Employer Branding experts.

\section{References}

- BOYETT, H.J.; BOYETT. J.T. (2000): World-class advice on managing and motivating people.http://www.jboyett.com/managing1.htm, downloaded: 2014.05.02.

- DUMA, F. (2014). Promoting the entreprenurship education in Europe, Online Journal Modelling the New Europe, (10), pp. 67-79.

- TÓTHNÉ SIKORA, G. (2004): Humán eröforrások gazdaságtana, Bíbor Kiadó (Hungarian)

- FODOR, M.; JAECKEL, K. (2017): What does it take to have a successful career through the eyes of generation $\mathrm{Z}$ - based on the results of a primary qualitative research, International Journal of Lifelong Education and Leadership 4:(1). pp.1-7.

- GARDA, I. (2009): A motiváció elméletei, http://mlmhogyan.com/pszichologia/amotivacio-elmeletei, downloaded: 2013.10.05. (Hungarian)

- GÖNDÖR, A. (2003): Szervezeti viselkedés, Kézirat (Hungarian)

- Howell, H. (2000): Motivating and appreciating your staff http://v-pc.com/catanzaro/mgtinfo/newsletter/spring2000/motivat.htm, downloaded: 2015.04.22.

- PINK, D.H. (2010): Motiváció 3.0 Ösztönzés másképp, HVG Kiadó Zrt. 44.p. 
- KISSNÉ ANDRÁS, K. (2010): Hogyan motiválhatóak a különböző generációk tagjai? https://www.hrportal.hu/hr/hogyan-motivalhatoak-a-kulonbozo-generaciok-tagjai20100804.html, downloaded: 2017. 09.19. (Hungarian)

- KISSNÉ ANDRÁS, K. (2014): Lehet-e egységesen motiválni a különböző generációs munkaerőt? https://www.hrportal.hu/hr/lehet-e-egysegesen-motivalni-a-kulonbozogeneracios-munkaerot, downloaded: 2017. 09.21. (Hungarian)

- KLEIN, B.; KLEIN, S. (2008): A motiváció, Humánpolitikai szemle, 19. (7-8), pp. 31-57.

- KÓPHÁZI, A. K (2007): A motiváció szerepe a munkavállalói lojalitás megteremtésében, Humánpolitikai Szemle, 18. (4), pp. 51-56 (Hungarian)

- KOVACH, K. (1999): Employee Motivation: Addressing a Crucial Factor in Your Organization's Performance, Ann Arbor, MI: University of Michigan Press

- LAZÁNYI, K. (2014a): An Employer of My Liking. In: MichelbergerPál (szerk.) MEB 2014 conference, Management, Enterprise and Benchmarking in the 21st Century. pp. 211-220.

- LAZÁNYI, K. (2014b). Entrepreneurial skills and competencies of students at Óbuda University. On-line Journal Modelling the New Europe, (10), pp. 17-28.

- LAZÁNYI, K. (2015): What makes a start-up successful? - Small business ventures in focus, On-line Journal Modelling the New Europe, (16), pp. 68-79.

- PINK, D.H. (2010): Motiváció 3.0 Ösztönzés másképp, HVG (Hungarian)

- RIDDERSTRALE, J.N (2004): Karaoke Kapitalizmus - Az emberiség menedzsmentje, Wolters Kluver (Hungarian)

- TARI, A. (2010): Y generáció - Klinikai pszichológiai jelenségek és társadalomlélektani összefüggések az információs korban, Jaffa Kiadó (Hungarian)

- TARI, A. (2011): Z generáció Tercium Kiadó (Hungarian)

- TÖRÖCSIK, M. (2003): Fogyasztói magatartás - Trendek. Budapest: KJK. (Hungarian)

- Top 6 munkaerö-piaci trend hrportal.hu:https://www.hrportal.hu/hr/jonnek-a-nyugdijasdolgozok---top-6-munkaero-piaci-trend-2017-ben-20170216.html, downloaded: 2017.10.02. (Hungarian) 
Issue no. $27 / 2018$

- TÓTH, J. (2009): Személyiségpszichológia

http://mlmhogyan.com/pszichologia/tag/skinner, downloaded: 2012.12.15. (Hungarian)

- BESSEL, I.; DICKS, B.; WYSOCKY, A.; KEPNER, K.; FARNSWORTH, D.; CLARK, J.L. (2017): Understanding motivation: an effective tool of managers, http://edis.ifas.ufl.edu/pdffiles/HR/HR01700.pdf, downloaded: 2017. 10.25. 